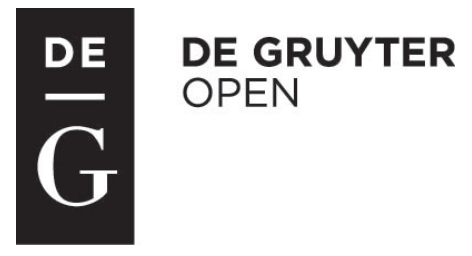

Przedsiębiorczość i Zarządzanie Entrepreneurship and Management University of Social Sciences Publishing House

ISSN $1733-2486$

Volume XV, Issue 2, pp. 131-141

DOI 10.2478/eam-2014-0022

Iwona Dorota Czechowska

University of Social Sciences

\title{
The importance of older people's participation in the financial services market
}

\begin{abstract}
The article presents definitions on population aging, characterises the analysed group of population, and discusses selected aspects of its activity in the financial services market. Its purpose has been to determine the importance of the elderly as the users of financial services. As demonstrated, the activity of customers aged $60+$ in the financial services market is of significance for various players in this market, as well as from the micro and macro perspective. The hypothesis that this subject area is neither sufficiently known nor recognized has been proved to be true. To improve the situation, financial institutions should analyse in detail the needs of elderly customers to develop targeted products and services, while older people should be more active and use them more often.
\end{abstract}

Key-words: financial services market, elderly people.

\section{Introduction}

One of macroeconomic goals is financial stability that depends, inter alia, on the efficiency of the financial system, which is determined by relations between financial intermediaries and their customers. With demographic forecasts predicting an increase in the proportion of the elderly population, people aged $60+$ are becoming an important and desired ${ }^{16}$ group of customers. Dynamic demographic changes following from the aging of populations [Prognoza 2009 , p. 308] are addressed in various fields of science. One of them is gerontology, an interdisciplinary and holistic science combining the elements of biology, psychology, cultural anthropology, sociology, pedagogy, demography,

\footnotetext{
${ }^{16}$ Most respondents $(87 \%)$ surveyed by CBOS are of the opinion that society needs older people: Polacy wobec ludzi starszych i wtasnej starości. Raport CBOS, BS/157/2009, Warszawa, p. 1.
} 
medicine (geriatrics) and economics [more: Jurek 2012, Bombol, Słaby 2011, Kleer 2008].

Population aging viewed in terms of public money spend to maintain elderly people and to cater for their needs is called „apocalyptic demography” [Ed. Gee, Gutman 2000, as quoted Golinowska 2012, p. 134]. A more optimistic approach that has been developed in response is called "silver economy", where supply is adjusted to the needs of older citizens with a view to stimulating the economy and thereby ensuring economic development and growth. In the silver economy, the needs of the aging population are analysed with respect to the assumption that meeting them is beneficial for the public at large, because the process brings new jobs and increases employment [Golinowska 2012, pp. 134-136].

The above facts have caused the author to conclude that the elderly population is as significant and interesting from the theoretical perspective as important for the economy. The public also seems to need more specific information on this subject. The decision to investigate this area followed from a critical review of the literature, which revealed a limited number of studies and publications on the users of financial services aged $60+$.

The innovative dimension of the research on the economic aspects of old age is proven by the fact that there are few reports on older customers in the market for lending and investment products offered by banks and unregulated providers, despite the subject becoming increasingly popular (J.K. Solarz indicated that the issue of population aging was raised in 1956 in the publication: The Aging of Populations and its Economic and Social Implications, Population Studies, United Nations, New York, 26/1956 [Solarz 2012, p. 85]) and attracting more and more researchers. This noticeable gap makes it worthwhile to study the activity of people aged $60+$ in the financial services market.

The main purpose of this investigation is therefore to determine the importance of older people's participation in the financial services market. In accomplishing it, notions related to aging are presented, the analysed group of population is characterised, and problems surrounding its activity in the financial services market are investigated. The presentation starts with a hypothesis that older people's participation in the financial services market is inadequately recognised and appreciated.

\section{Theoretical approaches to old age and the characteristics of the elderly population}

Researchers exploring the population aging issues has been interested so far in developing a definition of aging, finding its characteristics, and determining the chronological age from the perspective of the labour market and healthcare needs. The psychological and social aspects of aging have been studied along- 
side biological processes bringing about perceptual, motor, and psychological changes, as well as affecting social roles. To develop aging theories [Modrzejewski 2007, pp. 201-212] accounting for the human psycho-physical condition, life situation and participation in public life the following criteria have been used [Leszczyńska-Rejchert 2005, p. 18]: biological (changes in physiological functions), psychological (changes affecting psychological processes, personality and personal experiences) and socio-economic. The typology of elderly people has been discussed by: B. Barak, L.G. Schiffman, M. Salomon, G. Bamossy, and S. Askegard, G.P. Moschis [Bombol, Słaby 2011, pp. 111114, Bylok 2013, pp. 124-129].

The disadvantages and advantages of old age have also been studied. The first category includes increased incidence of chronic diseases, reduced physical fitness, the loss of family members and friends, problems with filling free time, a feeling of being useless, and financial problems. The assets of old age are free time to pursue one's interests, life experience and financial resources. The literature on aging offers many theories that explain attitudes held by senior citizens, as well as how they are perceived by the society. These are [OsieckaChojnacka 2012, p. 103]:

- the theory of exclusion which holds that aging causes a gradual withdrawal from previous roles and the weakening of emotional ties with the milieu and of vital forces.

- the continuity theory stating that human personality develops over the lifetime, and stressing human adaptability.

- the exchange theory pointing out that health and financial resources decrease while people are growing old, so they withdraw from interactions, e.g. from the labour market, once they discover their productivity to be lower than it used to be.

- the theory of selection, optimisation and compensation according to which good aging can be achieved by selecting the activities one wants to pursue, by acquiring new skills to become more efficient, by optimising performance, and by utilising various devices and equipment.

- the activity theory assuming that involvement in various activities ensures good old age and relatively good health in this period of life.

The theories underpin the active aging concept that recommends redefining one's priorities, giving up some life roles, and seeking new occupational, family and social activities.

The issue of population aging has been addressed by the Community and Member States that have taken measures to create the necessary state structures and to encourage research [The national plan... 2012]. The European Union designated the year 2012 as the European Year for Active 
Aging and Solidarity Between Generations to give prominence to the fact that Europe needs to promote a culture of activity of the older population and to foster the development of societies embracing all age groups [Active Ageing... 2012]. The challenges of population aging have also been addressed in the strategic part of the Polish presidency's programme in the EU Council. Major UN documents on the elderly people include the Vienna International Plan of Action on Aging (Vienna 1982) and the Madrid International Plan of Action on Ageing (Madrid 2002). In Poland, following the decision of the President of the Council of Ministers of 16 August 2012 the Department of Senior Policy was established as part of the Ministry of Labour and Social Policy. Its responsibilities range from setting the objectives and developing measures for senior citizens to the coordination of the Government Programme for Senior Citizens' Social Activity 2012-2013 ${ }^{17}$. The third activity in this field, enhancing the preparation of documents on aging and the creation of institutions to actively respond to its aspects, has been studies conducted by institutions such as the Eurobarometer, the Public Opinion Research Centre [CBOS report 2012] (CBOS), Pol-Senior [Błędowski, Mossakowska, Więcek 2011] and National Bank of Poland.

Old age, particularly active aging, is studied from many scientific perspectives which leads to the creation of various theoretical approaches explaining its nature. A more practical interest in aging can also be observed to increase. Even so, the literature offers few studies on the activity of consumers aged $60+$ in the financial services market, despite their growing significance for this market. This new role of older consumers makes financial institutions face the challenge of winning them for their business and of answering the question about what satisfying and fulfilling services can be offered to them so that their relatively unrecognised potential can be exploited.

Different resources, life experiences, social and occupational roles, as well as outlooks on life make seniors a heterogeneous group. They also differ in respect of demographic and socio-economic attributes and market activity. The Polish GUS' Household Budgets reports investigating households' levels of incomes, expenditures and poverty show those run by old age pensioners to have a relatively good situation compared with their other types, which makes them an interesting target group for financial intermediaries. The main source of livelihood of seniors is old age pension, while savings and gains from investments and deposits are rather infrequent. This means that the financial market should consider taking measures to develop lending and investment products addressed to seniors and consistent with their profile (table 1).

\footnotetext{
${ }_{17}$ The regulation no 68 by the President of the Council of Ministers of 16 August 2012 granting a statute to the Ministry of Labour and Social Policy (Monitor Polski of 17 Aug. 2012, item. 590). Ombudsman's regulation no. 8 of 2011 establishing Ombudsman's Commission of Experts for Older People.
} 
Table 1. The sources of livelihood of respondents drawing old age pensions $(\mathrm{N}=297)$, whether primary or secondary $(\%)$

\begin{tabular}{|l|l|l|}
\hline What is your present source of livelihood, whether primary or secondary: & Yes & No \\
\hline Old age pension & 89 & 10 \\
\hline Assistance from family members (children and relatives) & 12 & 88 \\
\hline Savings & 9 & 90 \\
\hline Disability pension & 6 & 94 \\
\hline Farm & 5 & 95 \\
\hline Family pension & 4 & 96 \\
\hline Odd jobs & 4 & 96 \\
\hline Maintained by a spouse & 4 & 96 \\
\hline Steady employment & 3 & 97 \\
\hline Own-account employment & 2 & 98 \\
\hline Additional life insurance (III pillar) & 2 & 98 \\
\hline Revenue from investments and deposits & 1 & 99 \\
\hline Social welfare benefit & 1 & 99 \\
\hline Revenue from rented space (a flat or a house) & 1 & 99 \\
\hline Others & 1 & 99 \\
\hline
\end{tabular}

Source: Sytuacja ludzi starszych w spoteczeństwie-plany a rzeczywistość. Raport CBOS, BS/160/2009, p. 7.

The functioning of customers aged $60+$ in the financial market depends on the availability of anti-usury laws and macro-stability tools (e.g. caps on the loan-to-value ratio $(\mathrm{LtV})$ or the debt-to-loan ratio $(\mathrm{DtL}))$, responsible lending rules, the protection of consumers' economic interests and the prevention of financial exclusion. In analysing the activity of this group of customers in the financial services market lending products offered by banks and unregulated financial intermediaries and their take up must also be considered, because this approach allows the potential of older consumers and their activity in that market to be determined vis-à-vis the identified barriers. It also enables the effectiveness of the existing instruments to be assessed and the optimal policy in this area to be defined. Moreover, in investigating consumer lending activity the perspective of both banks and unregulated financial intermediaries must be taken into account. These issues are relatively new and important for financial stability, but at the same time outside the scope of banking supervision, so the results of their analysis will have major practical implications [Kotliński, Waliszewski (eds) 2012, pp. 175-191].

\section{The reasons why customers aged $60+$ should be active in the financial services market}

Making financial intermediaries enable people aged 60+ to have appropriate and safe access to finance seems vital not only from the microeconomic per- 
spective, i.e. the ability of these customers to afford the purchase of various goods, but also for the progress of civilisation, because instead of being viewed only through the public finances' costs of their maintenance, the elderly and their needs will be recognised as a factor in economic development.

The above means that older people's activity in financial markets is a socially important and topical issue. At the same time, it is relatively new and little unrecognised by theory and practice. What makes it worth exploring is its demographic, as well as economic and social impacts. If a positive view on old age is to be taken, then it should not be perceived as a period of stagnation, but as another part of the lifetime when people are aware, have the basic knowledge of consumer technology, and are active, also in the banking services market.

With the aging of population it becomes necessary to develop products addressing the special needs of older consumers. Another reason why these products should be delivered is that the activity is in line with the sustainable development and corporate social responsibility (CSR) concepts implemented by financial institutions (including banks). The concepts take account of environmental and social demands without compromising the business side. Their elements are, respectively, economic growth based on stronger social cohesion, reduction in social stratification, elimination of discriminatory practices and marginalisation, and initiatives serving the public good and enhancing the image of institutions attentive to human needs.

The public dimension of the banking intermediation business means that the providers of financial services should contribute to solving social problems in a manner respecting economic security, for instance by providing customers aged $60+$ with access to finance. This implies that the concept of financial sustainability stemming from the concept of sustainable development extends also to relations between financial institutions, particularly between banks and customers aged $60+$ that deserve special treatment because of their attributes (attachment to solutions they already know, insufficient knowledge, problems with understanding legal procedures and specialist financial terminology, expectation of direct interaction with the provider's staff, etc.) that expose them to greater risks. These unique attributes and the awareness that these consumers may be uninformed, careless, imprudent and susceptible to unfair business practices result in the tightening up of regulations serving the protection of their interests and preventing unfair competition. The legal system offers extended protection to consumers meeting special criteria, such as age, that make them a vulnerable group, exposed or prone to harm [Brocklenhurst, Laurenson 2008, p. 1354, as quoted Mikołajczyk 2012, p. 37].

There are many tools that businessmen can use to influence the behaviour of their customers, i.e. marketing and selling techniques, or mislead- 
ing, aggressive market practices or advertisements. In addition to unfair business practices, the financial services market is also troubled by ageism [Mikołajczyk 2012, pp. 37-54] that usually takes the form of refusal to lend to those deemed too old. Financial exclusion of population can be measured with access to saving instruments or the possession of a bank account that are the least frequent among old age pensioners and people aged 65+ [Solarz 2012, pp. 30-34] (see table 2). The reasons why people in this age group do not have bank accounts may be related to various forms of financial exclusion [Solarz 2012, p. 33], such as spatial exclusion caused by the remote location of a banking establishment; business exclusion arising from some segment of customers being rejected upfront because of the implemented business model; cost exclusion appearing when the cost of a service is not affordable; quality exclusion in cases when products and services fall short of customers' expectations; and self-exclusion determined by people's belief that products and services for individuals with low social status are not available.

Table 2. The socio-demographic characteristics of the holders of checking accounts (CA) (\%)

\begin{tabular}{|l|l|l|}
\hline Socio-demographic characteristic & CA holders & Non-holders of CA \\
\hline$<24$ & 70 & 30 \\
\hline $25-34$ & 93 & 7 \\
\hline $35-44$ & 96 & 4 \\
\hline $45-54$ & 88 & 12 \\
\hline $55-64$ & 68 & 32 \\
\hline $65>$ & 43 & 57 \\
\hline Old age pensioner & 50 & 50 \\
\hline Disability pensioner & 54 & 46 \\
\hline Pupil, student & 59 & 41 \\
\hline Unemployed & 69 & 31 \\
\hline Farmer & 83 & 17 \\
\hline Manual worker & 90 & 10 \\
\hline Entrepreneur & 93 & 7 \\
\hline Specialist & 98 & 2 \\
\hline Office employee & 99 & 1 \\
\hline
\end{tabular}

Source: J.K. Solarz, Nowi wykluczeni. Ryzyko finansowe codzienności, Studia i Monografie, Łódź-Warszawa 2012, SAN, pp. 28-29.

Not only do older people frequently feel that the banking system does not appreciate them, but also that it mistreats and discriminates them. The complaints that consumers lodge with the Polish Ombudsman's office every year confirm that it is really so. While admitting that banks are free to make busi- 
ness decisions, the Ombudsman has stressed that ageism violates the constitutional principle of human equality and dignity, so it is unacceptable ${ }^{18}$. Complaints are filed by consumers who were denied access to banking products on the grounds of age, which caused their financial exclusion and prevented them from fully participating in economic activity, ultimately leading to social exclusion. To counteract these practices, preventive measures addressed to banks and consumers aged 60+ are proposed, such as codes of ethics, good market practices, certificates for banks friendly to older customers, educational programmes, the appointment of banks' representatives for older customers, changes in regulations restricting lending.

Better relations between customers aged $60+$ and financial intermediaries would be advantageous for both sides. Being reliable and predictable, with regular incomes and paying their debts on time, older customers have the potential to become a factor driving the growth of the banking sector. Granted access to banking services they can not only purchase various goods and live better lives, but also take active part in the life of their communities, develop personally, live active lives, and use new technologies.

However, if both parties are to be satisfied, the banking institutions must bear in mind that these customers are a unique group that has special needs and concerns that must be well understood before banking products and services targeted to their needs can be developed. On the other hand, older people should be active, trust in the banking system, and be ready to handle new challenges, such as the use of new technologies.

Investigating older persons' participation in the financial services market is important for further development of the field of finance, because the findings can show how to make the financial system more effective by ensuring a better match between financial services and the needs of the expanding segment of customers aged 60+. Financial intermediaries will also benefit from this research, because they will be shown why this group of customers should be provided with access to finance and the benefits of doing so. As far as customers aged $60+$ are concerned, they will be able to understand how to seek funds from financial intermediaries according to the rules of ethics and consumer protection.

Last but not least, the findings of the research will be also important for the supervisory authorities and the law-making bodies, because the knowledge of older people's activity in the lending market and of the barriers they face will allow selecting mechanisms capable of eliminating the exclusion or discrimina${ }^{18}$ Sytuacja osób starszych, jako konsumentów na rynku usług bankowych, Zespół Prawa Administracyjnego i Gospodarczego Ombudsman's Office. Art. 32 of the Constitution of the Republic of Poland All persons shall be equal before the law. All persons shall have the right to equal treatment by public authorities. 2 . No one shall be discriminated against in political, social or economic life for any reason whatsoever. As quoted in Ombudsman's report, Osoby starsze, jako konsumenci na rynku ustug bankowych, 23 Jan. 2012, Ombudsman's Office. 
tion of older people and thereby of increasing their trust in the financial sector, which is particularly important in times when financial stability is at risk.

The undertaking of research with a view to creating a commercial financial system that will allow an increasing group of aging customers to stay active is also important for the advancement of civilisation, as it is said that people do not grow old but become old when they stop to develop and be active. This means that the research should aim to gain new knowledge for creating a society embracing all age groups, where older people will be neither discriminated nor excluded, and where their activity and the resulting demand will be important factors in economic development.

\section{Conclusions}

The above analysis of older people's participation in the financial services market has been undertaken to demonstrate that this subject is insufficiently known and recognised. The conclusion arising from the discussion is that this hypothesis is true. A more general conclusion offered by the review of issues in population aging, which presents a major challenge for governments, financial intermediaries, and communities, performed with regard to the seniors' use of financial services is that neither their providers nor their users are active enough given the scale of available opportunities. This finding is strong enough to try to modify the present attitudes of financial service providers and customers aged 60+. A banking sector evolving in this direction will be more effective financially and socially, and so its development will be more dynamic.

\section{Bibliography}

Błędowski P., Mossakowska M., Więcek A. (2011), Projekt badawczy PolSenior, Aspekty medyczne, psychologiczne, socjologiczne i ekonomiczne starzenia się ludzi w Polsce 2011 r., Międzynarodowy Instytut Biologii i Molekularnej i Komórkowej. Bombol M., Słaby T. (2011), Konsument 55+ wyzwaniem dla rynku, Oficyna wydawnicza SGH w Warszawie, Warszawa.

Brocklenhurst H., Laurenson M., (2008), A Concept Analysis Examining the Vulnerability of older people, "British Journal of Nursing", vol.17, nr 21.

Bylok F. (2013), Strategia zachowań konsumpcyjnych seniorów na rynku dóbr i ustug konsumpcyjnych, Problemy Zarządzania Wydział Zarządzania UW, Warszawa, vol. 11 nr. 1 (40), t. 1.

Golinowska S. (2012), Srebrna gospodarka-ekonomiczny wymiar procesu starzenia sie populacji [w:] Strategie dziatania w starzejacym się społeczeństwie, Tezy i rekomendacje, Rzecznik PO, Warszawa.

Jurek Ł. (2012), Ekonomia starzejacego się społeczeństwa, Difin, Warszawa. 
Kleer J. (red.) (2008), Konsekwencje ekonomiczne i spoteczne starzenia sie społeczeństwa, Polska Akademia Nauk Komitet Prognoz, „Polska 2000 PLUS”, Warszawa.

Kotliński G., Waliszewski K. (red.) (2012), Instytucje para bankowe na rynku ustug bankowych $w$ Polsce, CeDeWu.pl. Warszawa.

Leszczyńska-Rejchert A. (2005), Człowiek stary i jego wspomaganie w strone pedagogiki starości, Wydawnictwo Uniwersytetu Warmińsko-Mazurskiego, Olsztyn.

Mikołajczyk B. (2012), Międzynarodowa ochrona praw osób starszych, LEX a Wolters Kluwer business, Warszawa.

Modrzejewski J. (2007), Socjalizacja i uczestnictwo społeczne. Studium socjopedagogiczne, Wyd. Uniwersytetu im. A. Mickiewicza, Poznań.

Osiecka-Chojnacka J. (2012), Społeczne opinie o starości a wdrażanie idei aktywnego starzenia się, Studia BAS, nr 2 (30), (www.bas.sejm.gov).

Solarz J.K. (2012), Nowi wykluczeni. Ryzyko finansowe codzienności, „Studia i Monografie" nr 37, Łódź-Warszawa, SAN.

The Overselling of Population Aging: Apocalyptic Demography, Intergenerational Challenges and Social Policy(2000), Ed. E.M. Gee, G.Gutman, Toronto, Oxford University Press.

Active Ageing (2012), Report, Special Eurobarometer 378, European Commission, nr 1.

The national plan of activities in support of the European Year for Active Aging and Solidarity Between Generations of 2012 (2012), Ministerstwo Pracy i Polityki Społecznej.

Opinie o podniesieniu wieku i zmianach $w$ systemie emerytalnym (2012), Raport CBOS BS/40, Warszawa.

Polacy wobec ludzi starszych i wtasnej starości (2009), Raport CBOS, BS/157/, Warszawa.

Prognoza ludności na lata 2008-2035 (2009), GUS, Warszawa.

Sytuacja ludzi starszych w społeczeństwie-plany a rzeczywistość (2009), Komunikat z badan. Raport CBOS, BS/160, Warszawa.

Sytuacja osób starszych, jako konsumentów na rynku ustug bankowych, Zespół Prawa Administracyjnego i Gospodarczego BRPO, https://www.rpo.gov.pl/sites/default/ files/13279229450_0.pdf (10.10.2013)

The Aging of Populations and its Economic and Social Implications, Population Studies (1956), United Nations, New York, nr 26.

Konstytucja Rzeczpospolitej Polskiej z 2 kwietnia 1997.

The regulation no 68 by the President of the Council of Ministers of 16 August 2012 granting a statute to the Ministry of Labour and Social Policy ("Monitor Polski" of 17 Aug. 2012, item. 590). 
Ombudsman's regulation no. 8 of 2011 establishing Ombudsman's Commission of Experts for Older People, http://www.rpo.gov.pl/sites/default/files/Zarzadzenie_ nr_8_2011.pdf (30.10.2013). 